Volume 21 Number 1 June 2021. P. 27-49

https://doi.org/10.30603/au.v21i1.2173

\title{
The Hijrah Phenomenon in Tertiary Education in Indonesian: A Multidimensional Analysis of Moderate Religious Values
}

\author{
Hasse Jubba ${ }^{1}$, Dwi Nugroho ${ }^{2}$, Gina Destrianti ${ }^{2}$, Sholikhah ${ }^{2}$ \\ ${ }^{1}$ Universitas Muhammadiyah Yogyakarta \\ ${ }^{2}$ Universitas Gadjah Mada
}

\begin{abstract}
This article explored the phenomenon of hijrah among students at several universities in Indonesia. The data used was obtained through observation, interviews, and documentation studies. The findings found two conditions in the religious community that developed within the university. First, uncontrolled religious communities, such as the salaf community (hijrah), were affiliated with radical Islam, Salafi, Wahabi, and Muslim Brotherhood. They were not controlled to moderate religion, breaking unity and peace, like the salaf community. Second, the government could control society because it has a hierarchical line, such as student organizations. This article recommends a thorough study of the phenomenon of hijrah, which has recently become prominent not to deviate from the basic principles of hijrah itself as part of the overall practice of Islamic teachings (kaffah).
\end{abstract}

Keywords: Hijrah Phenomenon, Students, Radicalism Ideology, Religious Moderation

\section{Fenomena Hijrah di Perguruan Tinggi Di Indonesia: Analisis Multidimensi Nilai-nilai Keagamaan Moderat}

\begin{abstract}
Abstrak
Artikel ini mengupas fenomena hijrah di kalangan mahasiswa di beberapa perguruan tinggi di Indonesia. Data yang digunakan diperoleh melalui observasi, wawancara, dan studi dokumentasi. Temuan menemukan dua kondisi dalam komunitas keagamaan yang berkembang di lingkungan universitas. Pertama, komunitas agama yang tidak terkendali, seperti komunitas salaf (hijrah), berafiliasi dengan Islam radikal, Salafi, Wahabi, dan Ikhwanul Muslimin. Mereka tidak dikendalikan untuk memoderasi agama, merusak persatuan dan perdamaian, seperti komunitas salaf. Kedua, pemerintah dapat mengontrol masyarakat karena memiliki garis hierarkis, seperti organisasi kemahasiswaan. Artikel ini merekomendasikan kajian mendalam terhadap fenomena hijrah yang akhir-akhir ini mengemuka agar tidak menyimpang dari prinsip dasar hijrah itu sendiri sebagai bagian dari keseluruhan pengamalan ajaran Islam (kaffah).
\end{abstract}

Kata Kunci: Fenomena Hijrah, Mahasiswa, Ideologi Radikalisme, Moderasi Beragama.

Author correspondence

Email: hasse@umy.ac.id

Available online at http://journal.iaingorontalo.ac.id/index.php/au/index 
Hasse Jubba, Dwi Nugroho, Gina Destrianti Sholikhah

\section{A. Background}

Hijrah is a new social movement. ${ }^{1}$ among young people capable of increasing holiness ${ }^{2}$ and is widely depicted through fashion ${ }^{3}$ And social media. It raises a tendency of understanding that can produce justifications that blame, discriminate, and antagonize each other by ignoring the tradition of open and critical thinking. So far, hijrah has become a global phenomenon, ${ }^{4}$ carried out by religious communities and artists ${ }^{5}$ Furthermore, they targeted university students. Along with the massive migration movement in higher education, $23.4 \%$ of Indonesian students are exposed to radicalism (detik.com, 2019). There are around ten well-known universities where radicalism has developed, including UI Jakarta, IPB, ITB, UGM, UNY, UNIBRAW, UNAIR, UIN Jakarta, and UIN Bandung. ${ }^{6}$ Three main aspects, circumstances, behavior, and style (fashion), identify the hijrah community. ${ }^{7}$

The study of 'hijrah' in higher education still tends to look at the phenomenological changes of the movement, ${ }^{8}$ Not evaluating the psychological and

1 Suci Wahyu Fajriani, "Hijrah Islami Milenial Berdasarkan Paradigma Berorientasi Identitas," Sosio Global : Jurnal Pemikiran dan Penelitian Sosiologi, Vol. 3 No. 2, (2019): 7788.

2 Amalia Taufik dan Taufik, M., "Hijrah as a Trend of Islamic Pop Culture among Students in Lombok, West Nusa Tenggara," Teosofia, Vol. 8, No. 2 (2020): 97-116.

${ }^{3}$ Siti Kholifah Pawestri dan Wisnu Pudji, "Fashion: Akumulasi Modal dan Habituasi pada Praktik Dakwah Komunitas Hijrah," Religious: Jurnal Studi Agama-Agama dan Lintas Budaya, Vol. 4, No. 3 (2020): 145-160; Meria Octavianti dan Nur Ratih Affandi, Komunikasi Dakwah Pemuda Hijrah." Jurnal Manajemen Komunikasi, Vol. 3, No. 2 (2019): 173-184.

4 Ina Goel, "Hijra Communities Of Delhi," Sexualities, Vol. 19, No. 5-6 (2016): 535-546.

5 Fathayatul Husna Yusri, "Kajian Musawarah: Contemporary Da'wah, Pious Identity and Virtual Ummah," Jurnal Ilmiah Islam Futura, Vol. 21, No. 1 (2021): 117-134; Indah Rama Jayanti Fitri dan Rahmi Nur, "Fenomena Seleb Hijrah: Tendensi Ekslusivisme dan Kemunculan Kelompok Sosial Baru," Muharrik: Jurnal Dakwah dan Sosial, Vol.2, No. 1 (2020): 1-17; Afrida Arinal Muna, "Religious Expression of Hijrah Celebrity: Accommodating Protest and Political Economy of Public Piety," Islam Realitas: Journal of Islamic \& Social Studies, Vol. 6, No. 1 (2020): 90-99.

${ }^{6}$ Muhamad Murtadlo, Menakar Moderasi Beragama di Perguruan Tinggi. Jakarta: Badan Litbang dan Diklat Kementerian Agama RI, 2019.

7 Penny Respati Yurisa, Irwan Abdullah, dan Muassomah, "The Meaning of Hijrah among Niqobers in Social Media," Analisa: Journal of Social Science and Religion, Vol. 5, No. 2 (2020): 201-220

8 Erik Setiawan, "Makna Hijrah pada Mahasiswa Fikom Unisba di Komunitas (Followers) Account Line@Dakwahislam," Mediator: Jurnal Komunikasi, Vol. 11, No 1 (2017): 127-151; Agnia Addini, "Fenomena Gerakan Hijrah Di Kalangan Pemuda Muslim Sebagai Mode Sosial," Journal Of Islamic Civilization, Vol. 1, No. 2 (2019): 109-118; Sulis Triyono Musahadah, Zahrina Sanni, "Fenomena Hijrah di Indonesia: Konten Persuasif dalam Instagram," Retorika: Jurnal Bahasa, Sastra, dan Pengajarannya, Vol. No. 9, No. 2 (2019): 90-163. 
ideological impact on each individual and group. Even though it can change to a positive matter, ${ }^{9}$ A hijrah is not infrequently inserted by studies that refer to radical, conservative religious understandings and hard-line religious studies leading to radicalism movements. The notion of radicalism itself has developed rapidly after the spirit of reform was launched in the spirit of fighting the new order both socially and politically. ${ }^{10}$ This community has accompanied the spirit of democracy, which impacts increasing the spread of radical Islamic understanding. This spirit is often able to enter into religious studies in hijrah groups both online and offline. Therefore, social media such as Facebook is hazardous due to limited sources of knowledge that many refer to as non-authoritative sources. ${ }^{11}$

The purpose of this paper is to complement the previous study by examining why the development of the hijrah community in universities has accompanied radical ideology on several campuses. This paper tries to look at the migration process among students in one of the religious campuses in Bandung and a public campus in Yogyakarta. The trend of migration among students is one of the gaps for the entry of radicalism through religious studies in it. The phenomenon of hijrah among students needs attention and assistance to not infiltrated the ideology of radicalism that encourages them to be intolerant. For this reason, this study will look at the hijrah process among students and the factors behind them emigrating. On the other hand, it will also reveal how the hijrah movement can change their thinking ideology.

This paper is based on a basic argument that the trend of migration among students as a global phenomenon in higher education can change the understanding of multiculturalism due to changes in social, cultural, and thought. Socially, the students' involvement in hijrah activities can gradually separate their understanding from other Islamic groups. On the other hand, hijra activities can also encourage communities to live more culturally conservative lives by

\footnotetext{
${ }^{9}$ Irmansyah, "Pemuda Hijrah: Antara Pietization dengan Lifestyle pada Komunitas Hijrah Yuk Ngaji Yogyakarta," Madania: Jurnal Ilmu-Ilmu Keislaman, Vol. 10, No. 1 (2020): 46-56. 10 M. Afif Ansori, "The Radical Islamic Movement in Indonesia: Roots And Factors," Kalam, Vol. 9, N0. 2 (2019): 217-236.

11 Deri Wanto Hidayat, Rahmad dan Muhammad Sholihin, "The Hijrah Communities and Religious Superficiality: Ideology and Religiosity of the Islamic Hijrah Communities on Social Media," Journal of Population and Social Studies, Vol. 9 (2020): 118 - 138.
} 
practicing pure religious teachings rooted in the thoughts of their predecessors. The hijrah group can spread radicalism, which ends in intolerant ideas and movements.

\section{B. Hijrah as a Religious Phenomenon}

Terminologically, 'hijrah' comes from the Arabic language, hajara-yahjuruhajaran, which means breaking off relations and leaving. While etymologically, ${ }^{12}$ 'hijrah' comes from hajara, hijra wa hujranan, which is the opposite of al-wasal which means to be continued, and its isim (noun) is al-hijrah which means the movement of a person from one place to another or from an area to other areas with the aim of good. In addition, the Qur'an itself states that there are several meanings regarding hijrah, firstly hijrah of the heart (QS. Al-Mu'minun: 67), secondly hijrah to save an aqeedah, where the last place has been damaged as usual (QS. An-Nisa':100). The three hijrahs are interpreted as moving from one bed to another, referring to husband and wife (QS. An-Nisa': 34). However, in its development, the hijrah should be expanded as an act of abandoning un-Islamic actions. ${ }^{13}$

Ibn Arabi defined hijrah into several meanings, including leaving the residence because of war, many heretics, bid'ah (innovation) perpetrators, sinful/forbidden acts, and saving souls and property. Therefore, hijrah for the spiritualists is a spiritual reality for every worshipper, especially for Muslims. Looking at the notion of hijrah in the Qur'an, hijrah must be related to three matters, avoiding something negative, fighting for religious teaching, and being religious according to the teachings. Therefore, in practice, hijrah must follow religious principles, both in physical and mental forms. ${ }^{14}$

In recent years, the phenomenon of hijrah that surrounds Muslims has increased dramatically. It is originated from social media as a means of da'wah,

\footnotetext{
12 Suarni, “Sejarah Hijrah dalam Perspektif Al-Qur'an," Jurnal Ilmiah Al-Mu'ashirah, Vol. 13, No. 2 (2017): 144-156.

13 Musa, "Tren Hijrah dan Isu Radikalisme dalam Meningkatkan Kualitas Masyarakat Islam," Sustainable: Jurnal Kajian Mutu Pendidikan, Vol. 2, No. 2 (2019): 245 - 264.

14 Aswadi, "Reformulasi Epistemologi Hijrah dalam Dakwah," Islamica: Jurnal Studi Keislaman, Vol. 5, No. 2 (2011): 339-352.
} 
friendship between Muslims by spreading advice post. Apart from being considered positive, this phenomenon also raises questions about whether the hijrah has some intentions. Many people claim hijra but do not at all comprehend its meaning. For them, hijrah means a migration change. Unfortunately, it comes with many incorrect religious perspectives, such as interpreting religion with long clothes, covering all bodies, beards, and turbans, and of course, thinking with a narrow view that religion is only limited to fashion. Still, the phenomenon of hijrah changes physical appearance and the way of thinking and religious spirit correctly.

From a social perspective, women who decide to wear the veil or niqab raise various questions when they declare their hijrah journey. These unfounded presumptions create a stigma that causes hijabi women intimidated from this religious environment. It will then lead to misunderstandings with other groups and be considered deviant. Hijrah is not only a matter of covering aurat (body parts required by Islam to be covered) but having the spirit of comprehending religious knowledge.

In today's religious context, religion has been demanded to move according to changing times and leave old traditions. Mass media technology defines religious movements, where they are the center of times. Muslims in this world are aware of how the sacred actions that have recently been motivated by the mass media, apart from creating a positive side to religion, have raised problems. They are sometimes not functioning correctly, seen from how several groups hurt religious values. ${ }^{15}$ Religion is also used as a political motive to gain votes, although religion and the state must work together. Hijra must include a better physical appearance and actions based on Islamic law. Thus, the spirit to migrate (hijrah) must be in harmony with the Qur'an and Sunnah and completed by broad scientific reasoning. Therefore, hijrah in religious phenomena is not limited to covering the aurat alone.

15 Jerico Mathias dan Siti Faridah, "Politisasi Agama Pemecah Keutuhan Bangsa dalam Pemilu," in Seminar Nasional Hukum Universitas Negeri Semarang, 2018. 


\section{Islam and Peace}

Religious moderation is a person's perspective and a way of respecting and responding to differences in religious diversity, racial disparities, ethnic differences, cultural differences, differences in customs, and ethical differences to maintain unity between religious communities and maintain solidarity. Religious moderation is an alternative to a middle ground amid diversity in Indonesia. Moderation goes hand in hand with not opposing each other between religion and local wisdom but seeking to solve problems with a tolerant attitude. ${ }^{16}$ Moderate perspective and attitude in faith are critical for a plural and multicultural society like Indonesia. However, religious moderation does not mean moderating religion because religion already contains moderation, called justice.

Phenomenologically, Islam in Indonesia is tolerant and moderate, as introduced by The Wali Songo. They offered a dialogical Islam that adhered to the values of monotheism Java in the past and da'wah or integrated much local culture with Islamic teachings. This synchronization is nothing more than an attempt to incorporate Islam into the local culture by offering the values of peace, safety for all human beings, not symbolic. Islam at that time reflected calm, peace, and tolerance from Sufism. ${ }^{17}$ Wali Songo is a Sufis and psychologist who could understand animism in Javanese society, thick with Hinduism and Buddhism.

The development of Islam in Indonesia has progressed rapidly to undermine animism, dynamism, Hinduism, and Buddhism ever since. Ahmad Syafii Maarif explained that Islam development could massively change people's beliefs in all directions except Bali, which still holds Hindu beliefs until now. ${ }^{18}$. Islam in several areas took many local cultural values to grow. In the end, Indonesian Islam was formed from the values. It has seven categories regarding the identity of Indonesian Islam. They are Nusantara Islam, Indonesian Islam, Javanese Islam

\footnotetext{
16 Agus Salim, "Peran dan Fungsi Dai dalam Perspektif Psikologi Dakwah," Al-Hikmah: Media Dakwah, Komunikasi, Sosial dan Budaya, Vol. 8, No. 1 (2018): 92-107.

17 Yuliyatun Tajuddin, "Walisongo dalam Strategi Komunikasi Dakwah," Addin: Media Dialektika Ilmu Islam, Vol. 8, No. 2 (2014): 367-390.

18 Firly Annisa, "Hijrah Milenial: Antara Kesalehan dan Populism," Maarif Institute, Vol 13, No. 1 (2018): 38-54 .
} 
(kejawen), Sasak Islam, Sharia Islam and Hatuhaha Indigenous Islam, Bubuhan Kumai Islam, and Coastal Islam. ${ }^{19}$

The term "Indonesian Islam" as the spirit of Islam integrated into locality, culture, and local necessity has not received global attention. Indonesian Islam from a sociological and anthropological point of view is closely related to regional values brought by Walisongo. The separation of this term is not merely a separation of Islam based on the Qur'an and Hadith, but a style of Islam that is closely related to local culture. Indonesian Islam shows another meaning of Islam that developed in Indonesia, Islam Nusantara. Azra, in this case, sees that Indonesian Islam is Islam with a different character from Islam in other countries. This difference is reflected in the process and application of religion in life.

On the other hand, Azra has also divided Islam that is developing in the world into eight groups, which he calls the Islamic Cultural Spheres: Indonesian Islam, Indian Islam (Bangladesh, India, and Pakistan), Sino Islam (East Asia), Iranian Islam. (Persia), Turkish Islam, African Islam, and Black Islam (SudanicAfrica/sub-Saharan, and Western Hemisphere). ${ }^{20}$

Indonesian Islam, in certain aspects, has its Islamic values based on cultural values. Indonesian Islam is close to the socio-history that shapes Indonesia. In other respects, Gus Dur called it the indigenization of Islam. This process is the history of Islam that takes the values and the teachings spread in Indonesia. Indigenization is not like Javanization and syncretism. Islam which is clashed with locality, considers the need to formulate a law that is close to the community's needs without changing the provisions of Islamic law itself.

\section{The Ideology of Change in Socio-Religious Movements}

According to Kuhn, the development of science starts from what is called a paradigm change (paradigm change) or a revolutionary paradigm shift (paradigm shift). Further, scientists are guided by a single paradigm in the typical science

19 Mujamil Qomar, "Ragam Identitas Islam di Indonesia dari Perspektif Kawasan," Epistemé: Jurnal Pengembangan Ilmu Keislaman, Vol. 10, No. 2 (2015): 317-352.

20 Irham Yuwanamu, "Bentuk Islam Faktual: Karakter Dan Tipologi Islam Indonesia," ElHarakah, Vol. 8, No. 2 (2016): 199-221. 
phase, and in this phase, scientists describe and develop the paradigm adopted. Thus, a single paradigm becomes the foundation for all scientific activities carried out by scientists. After the normal science phase, scientists began to be critical of the paradigm they adopted because scientists started to find anomalies in the paradigm because of the incompatibility of their theory with reality. Therefore, with this, this phase is referred to as the anomaly phase. When the anomaly phase becomes increasingly unstoppable, a crisis phase finally emerges after this crisis phase emerged a new paradigm which is considered the beginning of the development of science. Therefore, Hans Kung's paradigm change means that paradigm change is a process that runs revolutionarily. Unfortunately, there has never been a break. However, this paradigm change does not imply a paradigm switch, and it is possible to have two paradigms in a scientific community or even within a scientist. The possibility of these two paradigms competing with each other or gaining influence in which these two paradigms live together.

In religious understanding, this shift is strengthened by technological advances that can bring religious ideas to influence religious people. These religious notions have grown various new sects. Religious understanding is more likely seen as a process carried out intentionally and systematically by certain groups. The goals are also not for the nation's interests and the homeland but rather for certain groups that usually exist in other countries. The flow of understanding from one country to another involves religious understanding, which is transformed into specific groups, especially the most elderly groups, as targets of new religious beliefs. In Islamic religious understanding, there are several styles, such as fundamentalist, exclusive, normative theological, actual, rational, pluralist-inclusive, transformative, contextual, cultural, political, dynamic, modernist, and liberal. Therefore, changes in religious understanding lead to a lack of respect for the opinions of the ancient scholars. Thus, Hans Kung's paradigm change means that paradigm change is a process that runs revolutionarily. Unfortunately, there has never been a break. However, this paradigm change does not imply a paradigm switch, and it is possible to have two paradigms in a scientific community or even within a scientist. The possibility of these two 
paradigms competing with each other or gaining influence in which these two paradigms live together.

\section{E. Method}

The research method used was a qualitative approach with a descriptive research design. Descriptive research aims to know, understand, and describe the characteristics of the research focus, including humans, events, or situations. The results are presented in a descriptive narrative about complete and accurate pictures. This study explains how the hijrah process could be a bridge for radicalism to enter university students. Data collection techniques used were primary data and secondary data. Primary data was through observation and interviews, and secondary data was done through a literature review. The researchers did the interviews through various media such as face to face and the online zoom application. The respondents were three students from a university in Bandung and three students in Yogyakarta. The hypothesis proposed was that the trend of hijrah among students or young people had changed multicultural understanding.

\section{F. Result}

\section{Hijrah as a Student Communal Movement}

In-depth learning about Islam used to be primarily done in Islamic boarding schools, ${ }^{21}$ as the oldest educational institution, ${ }^{22}$ capable of synergizing with local culture, ${ }^{23}$ Nowadays, there are many dialogues in places and religious communities (hijrah) in the higher education environment. The spread and development of religious study communities in various universities is an interesting phenomenon that can invite young people (students) to explore religious studies (hijrah)

\footnotetext{
21 Musthofa, "Kedatangan Islam dan Pertumbuhan Pondok Pesantren di Indonesia Perspektif Filsafat Sejarah," An-Nuha, Vol. 2, No. 1, (2015): 1-15.

22 Babun Suharto, "Islam Profetik: Misi Profetik Pesantren sebagai Sumber Daya Ummat," Tadris: Jurnal Pendidikan Islam, Vol. 14, No. 1 (2019): 96-114.

23 Azra, Azyumardi, Afrianty, Dina and Hefner, Robert W. "Chapter 8. Pesantren and Madrasa: Muslim Schools and National Ideals in Indonesia". Schooling Islam, edited by Robert W. Hefner and Muhammad Qasim Zaman, Princeton: Princeton University Press, 2010, pp. 172-198.
} 
physically, mentally, and spiritually. ${ }^{24}$ Hijrah community in student circles is not a single phenomenon but originates from social trends and political upheavals. Through the new social spirit, hijrah does not stop at the study of religion but gradually entered into a reflected ideology in behavior, dress code, and communal religious relations. ${ }^{25}$

The spirit of hijrah among urban youth has started in the 1980s and is inseparable from the socio-political upheaval. This Islamization movement from other countries brought many global Islamic teachings such as Salafi Islam, Wahabi, Tablighi Jamaat, Muslim Brotherhood, Tarekat, and HTI. ${ }^{26}$ Hijrah has so far become a global phenomenon that is inseparable from efforts to Islamize all aspects, both in behavior, physical form, to the paradigm of thinking. Three primary efforts are often made when doing hijrah by changing the circumstances, behavior, and style (fashion) of a person or group. ${ }^{27}$ Changes in circumstances for the better are reflected in new social movements such as the hijab (niqab) for women and isbal clothing for men as an identity. ${ }^{28}$ This change in circumstances also targets many artists who want to increase their faith and piety. On the other hand, their existence can attract the sympathy of teenagers to follow the trend of emigration using social media accounts.

In the past, a religious understanding used to come from religious leaders and scholars. Now, it comes from spiritual, social communities, and religious leaders digitally. The hijrah method adapted to the needs and modernization (through technology) has illustrated how easy it is for people to migrate towards a life following the sharia. Hijrah communities have so far developed in various

\footnotetext{
${ }^{24}$ Erik Setiawan, "Makna Hijrah pada Mahasiswa Fikom Unisba di Komunitas (Followers) Account Line@Dakwahislam," Mediator: Jurnal Komunikasi, Vol. 11, No 1 (2017): 127-151. ${ }^{25}$ Agnia Addini, "Fenomena Gerakan Hijrah Di Kalangan Pemuda Muslim Sebagai Mode Sosial," Journal Of Islamic Civilization, Vol. 1, No. 2 (2019): 109-118.

26 Ibid.

27 Yurisa, Penny Respati, dan Muassomah, "The Meaning of Hijrah among Niqobers in Social Media."

${ }^{28}$ Muhammad Najib Azca, Yuyun Sunesti dan Noorhaidi Hasan, "Young Salafi-Niqabi and Hijrah: Agency and Identity Negotiation," Indonesian Journal of Islam and Muslim Societies, Vol. 8, No. 2 (2018): 173-198; Eva F Nisa, "Social Media and the Birth of an Islamic Social Movement: ODOJ (One Day One Juz) In Contemporary Indonesia," Indonesia and The Malay World, Vol. 46, No. 134 (2018):24-43.
} 
places with different goals and methods. Celebrities hijrah's journey, ${ }^{29}$ So far, it has played an essential role in spreading the spirit of hijrah to religious communities in the university environment. Using social media, producing content, and minimalistic delivery methods have attracted non-student youth to join the hijrah community by studying religion in-depth. ${ }^{30}$ And social media. ${ }^{31}$ Understanding faith wrapped in digitalization and religious figures (hijrah) can attract young people to explore religion rather than deepen religion in the boarding school environment which is not for a while.

\title{
2. Factors Triggering the Spread of the Hijrah Movement in Religious Moderation
}

How did the hijrah start, and what factors underlie it? This question will initiate the disclosure of the hijrah movement that occurs in higher education.

\begin{abstract}
"I tried to hijrah the end of high school but not to the actual stage yet. I was thinking of hijrah when my sister passes away. She was a pious person and liked to give me some advice. At first, I was annoyed because it was so complicated, but when my sister died, I felt so lost. I need someone to remind me. Then, I was looking for someone who could guide me to be the right person, at least someone who would remind me. I kept praying to meet good friends. Allah finally answered my prayer that I wanted to have a good environment from the power of prayer. For 1.5 years, I searched and kept praying. In the end, the people who stick around and the people were kind. As time went by, I continued to see how my friends behave, so I finally started to change little by little. From there, I started watching Islamic teachings on YouTube." (R1, female, 2021).
\end{abstract}

\footnotetext{
${ }^{29}$ Yusri, "Kajian Musawarah : Contemporary Da'wah, Pious Identity and Virtual Ummah", Jurnal Ilmiah Islam Futura, Vol. 21, No. 2 (2021): 117-134; Fitri, Rahmi Nur, "Fenomena Seleb Hijrah: Tendensi Ekslusivisme dan Kemunculan Kelompok Sosial Baru", Muharrik: Jurnal Dakwah dan Sosial, Vol. 3, No. 1 (2020): 1-17; Afrida Arinal Muna, "Religious Expression of Hijrah Celebrity: Accommodating Protest and Political Economy of Public Piety," Islam Realitas: Journal of Islamic \& Social Studies, Vol. 6, No. 1 (2020): 90-99; Afina Amna, "Hijrah Artis sebagai Komodifikasi Agama," Jurnal Sosiologi Reflektif, Vol. 13, No. 2 (2019): 331-350.

30 Bunga Mustika Syahrin dan Alif Alfi, "Makna Hijrah bagi Kalangan Remaja Non Santri: Dampak Penggunaan Media Sosial," Jurnal Studi Agama dan Masyarakat, Vol. 16, No. 1 (2020): 61-72.

31 Trie Yunita Sari dan Fatimah Husein, "Hijrah and Islamic Movement in Social Media: a Social Movement Study of Anti- Dating Movement \#Indonesiatanpapacaran," Dinika: Academic Journal of Islamic Studies, Vol. 5, No 1 (2020): 1-26.
} 
Modernization in many aspects, including religion, makes learning about Islam accessible through social media. It has offered convenience in deepening religious knowledge. This phenomenon shows that da'wah's digitalization. ${ }^{32}$ Can minimize the period and cost because they do not have to stand from one pulpit to another conventionally. Unfortunately, religious studies through social media today sometimes do not offer a complete understanding, even bias, and seem to do da'wah performances. ${ }^{33}$ Unlike in the past, da'wah is now minimalist but abandons existing socio-cultural values. In the past, many religious leaders took cultural values as a medium for preaching, which in fact, each region has different cultural values. $^{34}$

Social media from young people's lives allow digital media to have a positive impact on religious studies. Therefore, social media as a medium of da'wah has so far been effective in attracting the enthusiasm of young people.

"Initially, I was down because I failed SNMPTN and SBMPTN (State University National Entrance Exam). The point is, I felt useless because I could not go to college, and I was forced to take a break for about a year. From there, I felt something was missing. When I was down like that, a friend invited me to participate in my studies, inviting me to be closer to Allah. Thank God things were starting to change. I started from clothes, looser clothes, skirts, hijab covering the chest. When I entered college, I met more friends with better religious knowledge. A supportive environment that supported me added to the enthusiasm for hijrah. I wanted to be a better human being. So, I participated in studies on and off-campus." (R3, female, 2021)

The developing socio-cultural life in the community, hijrah, can influence someone to transform religious values in life. R3 started hijrah after being invited to participate in her friend's religious studies when her psychological condition was low due to failing college. Hijrah, in this case, requires a change in behavior

\footnotetext{
32 Erik Setiawan, "Makna Hijrah pada Mahasiswa Fikom Unisba di Komunitas (Followers) Account Line@Dakwahislam," Mediator: Jurnal Komunikasi, Vol. 11, No 1 (2017): 127-151. 33 Nur Ahmad, Tantangan Dakwah di Era Teknologi dan Informasi: Formulasi Karakteristik, Popularitas, dan Materi di Jalan Dakwah, Addin: Media Dialektika Ilmu Islam, Vol. 8, No. 2 (2014).

${ }^{34}$ Alif Jabal Kurdi, "Dakwah Berbasis Kebudayaan Sebagai Upaya Membangun Masyarakat Madani Dalam Surat Al-Nahl: 125," Jurnal Studi Ilmu-Ilmu Al-Qur'an dan Hadis, Vol. 19, No. 1 (2019): 21-42.
} 
and spiritual understanding. Communication in da'wah is inseparable from psychological aspects. Like Fisher's theory of communication ${ }^{35}$ Da'wah is closely related to psychological factors, including giving stimulants, receiving material by mad'u, remembering, and providing feedback. Islam and the teachings contain many positive values in the social and cultural dimensions that can motivate humans to carry out knowledge transformation practically and critically. ${ }^{36}$

Religious factors also influence someone to explore religion, such as what happened to the second informant states:

"My hijrah journey started from the environment. I skipped a year from high school to college. I took a boarding school in DT for one year because I had no activities. From there, the desire to become a more useful person began to grow. I started attending college as part of campus organizations. There I also studied da'wah and Islamic studies. From that organization, I regularly joined liqo every week. There, I learned about Islam and the foundation, also aqeedah and morals." (R2, male, 2021)

So far, R2 explained that his desire to hijrah started when he attended halaqah outside the campus. He became interested and began to take regular indepth studies on aqeedah and morality (R2 (male), 2021). Likewise, R4 explained that his reasons for hijrah were mistakes made in the past when he preferred the world to the afterlife (R4, (female), 2021). Several celebrities began to study religion in depth. Laudya Chintya Bella, as an example, thought that being beautiful, famous, and wealthy does not promise serenity and peace. She explained that stability and peace could be achieved once she got closer to Allah SWT in her turning point. ${ }^{37}$

"What encouraged me was that first I had feelings of guilt and regret for what I had done in the past. I was more concerned with worldly affairs and put aside the afterlife. Therefore, I tried to improve myself even better and get closer to Allah, and I want to balance the affairs of this world and the afterlife." (R4, female, 2021)

\footnotetext{
35 Salim, "Peran Dan Fungsi Dai Dalam Perspektif Psikologi Dakwah", Al-Hikmah, Vol. 9, No. 14 (2017): 92-107.

36 Ernita Dewi, "Transformasi Sosial Dan Nilai Agama," Jurnal Imlu-Ilmu Usuluddin dan Filsafat, Vol. 14, No. 1 (2012): 112-121.

${ }^{37}$ Neneng Irwanti, "Selebritas dan Transformasi Keagamaan: Citra Ganda Artis Perempuan Muslim," Jurnal Kajian Islam Interdisipliner, Vol. 5, No. 1 (2020): 69-82.
} 
On the other hand, the desire to participate in the hijrah community can also be motivated by the desire to change personality for the better and make it easier to communicate and socialize.

"I joined the hijrah community since the second grade of high school after joining the student council organization. In that organization, I saw that many of my friends were doing well. After I checked, it turned out that they were also involved in spiritual organizations. In the end, I decided to join an organization that discussed many things. So far, I have followed the LDK organization (FSLDK), which focuses a lot on regeneration in political movements. This movement is also widely carried out by graduate student organizations on this campus. I have also been involved in Salafi Islamic studies (not as a member), where its studies are a bit harsh.

On the other hand, I also participate in the Tarbiyah community (Wahda Islamiyah), which differs from the LDK by putting aside movements that lead to politics. Furthermore, I also participate in the yellow book review organization, mostly done at NU." (R6, male, 2021).

\section{Ideology Changes in Hijrah}

The hijrah movement reflects social movements from people with a collective identity and shared values, both formally and informally. ${ }^{38}$ The Youth Hijrah Community in Bandung, in which young people dominate, invites and changes personality for the better through religious studies related to everyday life. ${ }^{39}$ This new social movement forms a spiritual domain that invites and distributes pure Islamic thought.

How did hijrah change your ideology?

"Allah SWT wants every woman to cover her aurat from top to bottom, so I immediately corrected my way of dressing with my balance by adding knowledge and insight. Sometimes people will judge when someone wears a niqab to look radical. Yes, I think that everyone is free to change their appearance. They are free to preach, all of which are done in a pleasing way to Allah. Pros and cons are common. The most important thing is when I am determined to hijrah. My goal is to focus on getting closer to Allah. I am also inspired by clerics who often fill studies at campus mosques. They encourage people to move to a sacred path." (R4, female, 2021).

\footnotetext{
38 Nur Aziemah Binte Azman and Nur Azlin Mohd Yasin, "Islamic State's Online Social Movement Lifecycle," Terrorist Trends and Analysis, Vol. 8, No. 10 (2019): 3-7.

${ }^{39}$ A. N Fatoni, U. \& Rais, "Pengelolaan Kesan Da'i dalam Kegiatan Dakwah Pemuda Hijrah," Dakwah dan Komunikasi, Vol. 12, No. 2 (2018): 211-22.
} 
The ideological change is seen in halaqah, which puts aside life together. Several hijrah communities try to claim the truth of the teachings and interpretations of religious texts, causing a clash in ideology and action. The claim of the reality of the teachings in the religious community in the university environment, as explained by R5, that the hijrah he followed offered a new ideology in religion. The salaf community he participated in gave many tendencies to think hard by embodying life together and peace, among others (R5 (male), 2021). This phenomenon is a threat to local identity caused by the loss of aspects of morals, norms, ethics, spirituality to the dynamics of life. ${ }^{40}$ This euphoria can change the socio-religious order by attracting millennials to join the ease of access to technology. 41

"At first, I wanted to study religion more deeply, but after entering the Salaf community on campus, I felt something was up. In halaqah, they have a strong argument from the arguments. I think that ijtihad understands the arguments, but other sciences support mujtahids for ijtihad. They also question ikhtilaf, which even the scholars of the past never blamed each other for it. One more thing that they think as misguided other people who disagree with them." (R5, male, 2021).

Ustad and celebrities who popularized the hijrah movement through social media could construct how social activities enter as perspectives and change collective behavior. This process is a de-authorization of the role of Islamic boarding schools steeped in religion because modernization requires an understanding of religion through social media and an impromptu ustad with compelling characters and materials. The absence of solid vertical control makes new social movements potentially infiltrated by hard-line radical thoughts. This new social movement requires a simplification (shortening of phases) of religious understanding through community and social media. It involves the marginalization of ulama, Islamic boarding schools, and Islam in the archipelago. ${ }^{42}$

\footnotetext{
40 Rahmawati, "Peran Akhlak Tasawuf dalam Masyarakat Modern," Al-Munzir, Vol. 8, No. 2 (2015): 241-245.

${ }^{41}$ Firly Annisa, "Hijrah Milenial: Antara Kesalehan dan Populism," Maarif Institute, Vol 13, No. 1 (2018): 38-54 .

42 Raden Intan Sunarto, "Peran Pondok Pesantren Dalam Pengembangan Kultur Islam Nusantara," Al-Tadzkiyyah: Jurnal Pendidikan Islam, Vol. 6, No. 2 (2015): 185-197.
} 


\section{G. Discussion}

This study shows that the high hopes in the phenomenon of hijrah among students will increase the understanding of a calm and peaceful religion is not proven. Increasing understanding and the movement of radicalism within the Higher Education environment depend on the community and understanding. Many come from virtual practices, and specific religious communities that do not study religion can produce biased religious discussions. So far, religious communities within universities are closely related to transnational spiritual understanding. Even though not all hijrah communities are infiltrated by radical understandings, such as Salafi, Wahhabis, HTI, and Muslim Brotherhoods, the new social movement (hijrah) has been structured by community understanding. It is based on digital media, most of which have been exposed to radical thinking. At least ten universities in Indonesia have spread radicalism, such as UI Jakarta, IPB, ITB, UGM, UNY, UNIBRAW, UNAIR, UIN Jakarta, and UIN Bandung. ${ }^{43}$

Despite religious moderation, the exclusive religious community on campus can spread radical teachings to some of its followers through community halaqah. This condition began to be revealed when one of the students was involved in an international terrorist network. Although this understanding will be more targeted at public universities, students in religious universities cannot be separated from radicalism. ${ }^{44}$ Radicalism itself developed significantly after the fall of the New Order, which accompanied the spirit of democracy.45 This revival also attends social media that is not well controlled, increasing the radius of radical Islamic understanding. Social media platforms, such as Facebook, Instagram, and others, have shaped behavior and increase religious understanding in modern society. 46

43 Muhamad Murtadlo, Menakar Moderasi Beragama di Perguruan Tinggi. Jakarta: Badan Litbang dan Diklat Kementerian Agama RI, 2019.

44 Wahid Khozin, "Sikap Keagamaan dan Potensi Radikalisme Agama Mahasiswa Perguruan Tinggi Agama," Edukasi: Jurnal Penelitian Pendidikan Agama Ddan Keagamaan, Vol. 11, No. 3 (2013): 289-394.

${ }^{45}$ Ansori, "The Radical Islamic Movement in Indonesia: Roots And Factors," Kalam, Vol. 13, No. 2 (2019): 105-24.

46 Mona Abdel-fadil, "The Politics of Affect: The Glue of Religious and Identity," Journal of religion, media and digital culture, Vol. 8 Issue 1 (2019): 11-34; Ken Chitwood, "Latinx Muslims 'Like' One Another: an Ethnographic Exploration of Social Media and the Formation of Latinx Muslim Community," In Anthropological Perspectives on The Religious Uses of Mobile Apps, (2019): 83-104; Eva F Nisa, "Social Media and the Birth of an Islamic Social Movement: ODOJ (One Day One Juz) In Contemporary Indonesia," Indonesia and The Malay World, Vol. 46, No. 134 (2018):24-43. 
Social media to explore religion has so far been limited to non-authoritative sources. As a result, spiritual awareness is mainly constructed by the understanding community, hijrah figures, and virtual religious understanding to exclude Islamic boarding schools' roles, ulama, and Kiai.

Transnationalization ${ }^{47}$ Since the reformation has become a common threat when radicalism has entered the action stage, radicalism is not a problem as long as it is ideological thought. However, when it shifts to the realm of movement, it will become a problem followed by violence and acts of terrorism. ${ }^{48}$ In a sense, radicalism in thought is called fundamentalism, while in action, it is called terrorism. ${ }^{49}$ Thinking radical is allowed, according to KH. Hasyim Muzadi as long as he does not move towards radicalism and ends up in radicalization processes. However, the freedom to think radically should be balanced with the spirit of religious moderation as a filter. Although incomplete, radical thinking has the potential to foster radicalism ideology, and then it can develop to be reactive in radicalization. 50

This research reveals two conditions in the religious community that develops within the university. First, uncontrolled religious communities, the salaf (hijrah) community, are affiliated with radicalism. Salafi, Wahhabis, Muslim Brotherhood, and others are not controlled to moderate religion to break the values of unity and peace in the salaf community. It can happen at any time because even the most influential religious organizations in Indonesia, both NU, and Muhammadiyah, have infiltrated by radical understanding. ${ }^{51}$ Second, the government can control communities because they have a hierarchical line, such as student organizations. However, the organization may be infiltrated by radical understanding when the wave of hijrah and da'wah continues to be rolled out

47 Masdar Hilmy, "Akar-Akar Transnasionalisme Islam Hizbut Tahrir Indonesia (HTI)," Islamica: Jurnal Studi Keislaman, Vol. 6, No. 1 (2011): 1-13.

48 Endang dan Riza Sihbudi Turmudzi, Islam dan Radikalisme di Indonesia, (Jakarta: LIPI Press, 2005).

49 Rahimi Sabirin, Islam dan Radikalisme, (Yogyakarta: Ar-Rasyid, 2004).

50 Abu Rokhmad, "Radikalisme Islam dan Upaya Deradikalisasi Paham Radikal," Walisongo: Jurnal Penelitian Sosial Keagamaan, Vol. 20, No. 1 (2012): 79-114.

51 Zaimul Asroor, "Islam Transnasional vs Islam Moderat: Upaya NU dan Muhammadiyah dalam Menyuarakan Islam Moderat di Panggung Dunia," At-Turas: Jurnal Studi Keislaman, Vol. 6, No. 2 (2019): 31-73. 
through social media.52 The biggest problem facing Indonesia in religious moderation is the spirit of religious conservatism. ${ }^{53}$

The influx of students from year to year, which is not controlled as a whole, deradicalize religion to hit the scale. ${ }^{54}$. The number of students who are not ideologically controlled cannot stop radicalism through covert channels. ${ }^{55}$ The number of students who are not ideologically controlled cannot stop radicalism through secret channels. ${ }^{56}$ The exposure of the two largest religious organizations in Indonesia, such as NU and Muhammadiyah, shows that this understanding can enter through minor gaps. So far, Azra sees that Indonesian Islam is still being suppressed by conservative Muslims or Islamic populism. ${ }^{57}$ Therefore, it is essential to actualize moderation in well-organized efforts both individually and communally. For this reason, self-control through a complete understanding of religion must be presented and adapted to traditional knowledge materials. In addition, it is crucial to restoring the function of Islamic boarding schools as a filter for moderate religious development as collective control.

Relying on community understanding and religious learning through social media will only narrow spiritual experience. From the above phenomena, it is undoubtedly necessary to provide a source of knowledge about Islam that is calm, peaceful, and tolerant through structured efforts. The embodiment of moderation in higher education should be integrated with the modernization of social media can be well directed and filtered from radicalization efforts. This preventive effort

52 Muhammad Ali Chozin, "Strategi Dakwah Salafi di Indonesia," Jurnal Dakwah, Vol. 16, No. 1 (2013): .

53 Muhammad Zuhdi, "Challenging Moderate Muslims: Indonesia's Muslim Schools in the Midst of Religious Conservatism," Religions, Vol. 9, No. 10 (2018): 1-15.

${ }^{54}$ Syamsul Arifin \& Hasnan Bachtiar, "Deradikalisasi Ideologi Gerakan Islam Transnasional Radikal," Jurnal Multikultural \& Multireligius, Vol. 12, No. 3 (2013): 19-36.

55 Agusman Damanik Arifinsyah, Arifinsyah, Safria Andy, "The Urgency of Religious Moderation in Preventing Radicalism in Indonesia," Esensia: Jurnal Ilmu-Ilmu Ushuluddin, Vol. 21, No. 1 (2020): 91-108.

56 Zaimul Asroor, "Islam Transnasional vs Islam Moderat: Upaya NU dan Muhammadiyah dalam Menyuarakan Islam Moderat di Panggung Dunia," At-Turas: Jurnal Studi Keislaman, Vol. 6, No. 2 (2019): 31-73.

57 Muhammad Zuhdi, "Challenging Moderate Muslims: Indonesia's Muslim Schools in the Midst of Religious Conservatism," Religions, Vol. 9, No. 10 (2018): 1-15. 
will have many positive impacts on suppressing the spread of radicalism in the university environment.

\section{H. Conclusion}

This study contributes to the narrative of a new phenomenon about Islam and the dynamics of Muslim fashion in Indonesia. Empirically, this study shows that respondents who become informants travel to migrate with different motivations. Some experience adversity and despair when they lose someone, or they do not get what they expect. On the other hand, some parties involved in implementing this hijrah are the closest people, such as friends and relatives, through invitations to participate in various studies or join a particular organization. The studies followed by the informants were not only limited to faceto-face studies but were also conducted online through YouTube, Instagram, and Facebook. At several universities, informants stated that they had participated in halaqa activities or also known as liqo. In these activities, informants were taught several things about religious knowledge and Islamic knowledge. Among them are how to dress appropriately according to sharia and how faith is formed through learning aqeedah and morals. Therefore, there are various kinds of changes experienced by informants, not only from changes in appearance but also changes in thinking. As one of the da'wah institutions that distribute knowledge and knowledge, universities must limit or pay attention to various kinds of studies conducted by universities. Not only that, but universities can also pay full attention to their students and educators. Thus, the hijra movement among youth can bring positive nuances and prevent them from unwanted radical influences.

\section{References}

A. N Fatoni, U. \& Rais. "Pengelolaan Kesan Da'i dalam Kegiatan Dakwah Pemuda Hijrah," Jurnal Dakwah dan Komunikasi, Vol. 12, No. 2 (2018): 211-22.

Abdel-Fadil, Mona. "The Politics of Affect: The Glue of Religious and Identity," Journal of Religion, Media and Digital Culture, Vol. 8 Issue 1 (2019): 11-34.

Addini, Agnia. "Fenomena Gerakan Hijrah di Kalangan Pemuda Muslim Sebagai Mode Sosial," Journal Of Islamic Civilization, Vol. 1, No. 2 (2019): 109-118.

Ahmad, Nur. Tantangan Dakwah di Era Teknologi dan Informasi: Formulasi Karakteristik, Popularitas, dan Materi di Jalan Dakwah, Addin: Media Dialektika Ilmu Islam, Vol. 8, No. 2 (2014). 
Amna, Afina. "Hijrah Artis sebagai Komodifikasi Agama," Jurnal Sosiologi Reflektif, Vol. 13, No. 2 (2019): 331-350.

Annisa, Firly. "Hijrah Milenial: Antara Kesalehan dan Populism," Maarif Institute, Vol 13, No. 1 (2018): 38-54.

Ansori, M. Afif. "The Radical Islamic Movement in Indonesia: Roots And Factors," Kalam, Vol. 9, N0. 2 (2019): 217-236.

Ansori. "The Radical Islamic Movement in Indonesia: Roots And Factors," Kalam, Vol. 13, No. 2 (2019): 105-24.

Arifin, Syamsul \& Hasnan Bachtiar, "Deradikalisasi Ideologi Gerakan Islam Transnasional Radikal," Jurnal Multikultural \& Multireligius, Vol. 12, No. 3 (2013): 19-36.

Arifinsyah, Agusman Damanik, et al. "The Urgency of Religious Moderation in Preventing Radicalism in Indonesia," Esensia: Jurnal Ilmu-IImu Ushuluddin, Vol. 21, No. 1 (2020): 91-108.

Asroor, Zaimul. "Islam Transnasional vs Islam Moderat: Upaya NU dan Muhammadiyah dalam Menyuarakan Islam Moderat di Panggung Dunia," At-Turas: Jurnal Studi Keislaman, Vol. 6, No. 2 (2019): 31-73.

Aswadi. "Reformulasi Epistemologi Hijrah dalam Dakwah," Islamica: Jurnal Studi Keislaman, Vol. 5, No. 2 (2011): 339-352.

Azca, Muhammad Najib et al. "Young Salafi-Niqabi and Hijrah: Agency and Identity Negotiation," Indonesian Journal of Islam and Muslim Societies, Vol. 8, No. 2 (2018): 173-198.

Azman, Nur Aziemah B and Nur Azlin Mohd Yasin. "Islamic State's Online Social Movement Lifecycle," Terrorist Trends and Analysis, Vol. 8, No. 10 (2019): 37.

Azyumardi, Azra, et.al. "Chapter 8. Pesantren and Madrasa: Muslim Schools and National Ideals in Indonesia". Schooling Islam, edited by Robert W. Hefner and Muhammad Qasim Zaman, Princeton: Princeton University Press, 2010, pp. 172-198.

Chitwood, Ken. "Latinx Muslims 'Like' One Another: an Ethnographic Exploration of Social Media and the Formation of Latinx Muslim Community," In Anthropological Perspectives on The Religious Uses of Mobile Apps, (2019): 83-104.

Chozin, Muhammad Ali. "Strategi Dakwah Salafi di Indonesia," Jurnal Dakwah, Vol. 16, No. 1 (2013): .

Deri Wanto Hidayat, Rahmad dan Muhammad Sholihin, "The Hijrah Communities and Religious Superficiality: Ideology and Religiosity of the Islamic Hijrah Communities on Social Media," Journal of Population and Social Studies, Vol. 9 (2020): 118 - 138.

Dewi, Ernita. "Transformasi Sosial dan Nilai Agama," Jurnal Imlu-Ilmu Usuluddin dan Filsafat, Vol. 14, No. 1 (2012): 112-121. 
Endang dan Riza Sihbudi Turmudzi. Islam dan Radikalisme di Indonesia, Jakarta: LIPI Press, 2005.

Fajriani, Suci Wahyu. "Hijrah Islami Milenial Berdasarkan Paradigma Berorientasi Identitas," Sosio Global : Jurnal Pemikiran dan Penelitian Sosiologi, Vol. 3 No. 2, (2019): 77-88.

Fitri, Rahmi Nur. "Fenomena Seleb Hijrah: Tendensi Ekslusivisme dan Kemunculan Kelompok Sosial Baru”, Muharrik: Jurnal Dakwah dan Sosial, Vol. 3, No. 1 (2020): 1-17.

Goel, Ina. "Hijra Communities Of Delhi," Sexualities, Vol. 19, No. 5-6 (2016): 535546.

Hilmy, Masdar. "Akar-Akar Transnasionalisme Islam Hizbut Tahrir Indonesia (HTI)," Islamica: Jurnal Studi Keislaman, Vol. 6, No. 1 (2011): 1-13.

Irmansyah. "Pemuda Hijrah: Antara Pietization dengan Lifestyle pada Komunitas Hijrah Yuk Ngaji Yogyakarta,” Madania: Jurnal Ilmu-Ilmu Keislaman, Vol. 10, No. 1 (2020): 46-6.

Irwanti, Neneng. "Selebritas dan Transformasi Keagamaan: Citra Ganda Artis Perempuan Muslim," Jurnal Kajian Islam Interdisipliner, Vol. 5, No. 1 (2020): 69-82.

Jayanti, Indah Rama dan Rahmi Nur Fitri. "Fenomena Seleb Hijrah: Tendensi Ekslusivisme dan Kemunculan Kelompok Sosial Baru," Muharrik: Jurnal Dakwah dan Sosial, Vol.2, No. 1 (2020): 1-17.

Khozin, Wahid. "Sikap Keagamaan dan Potensi Radikalisme Agama Mahasiswa Perguruan Tinggi Agama," Edukasi: Jurnal Penelitian Pendidikan Agama dan Keagamaan, Vol. 11, No. 3 (2013): 289-394.

Kurdi, Alif Jabal. "Dakwah Berbasis Kebudayaan Sebagai Upaya Membangun Masyarakat Madani Dalam Surat Al-Nahl: 125," Jurnal Studi Ilmu-Ilmu AlQur'an dan Hadis, Vol. 19, No. 1 (2019): 21-42.

Mathias, Jerico dan Siti Faridah. "Politisasi Agama Pemecah Keutuhan Bangsa dalam Pemilu," in Seminar Nasional Hukum, Universitas Negeri Semarang, 2018.

Muna, Afrida Arinal. "Religious Expression of Hijrah Celebrity: Accommodating Protest and Political Economy of Public Piety," Islam Realitas: Journal of Islamic \& Social Studies, Vol. 6, No. 1 (2020): 90-99.

Murtadlo, Muhamad. Menakar Moderasi Beragama di Perguruan Tinggi. Jakarta: Badan Litbang Dan Diklat Kementerian Agama RI, 2019.

Musa. "Tren Hijrah dan Isu Radikalisme dalam Meningkatkan Kualitas Masyarakat Islam," Sustainable: Jurnal Kajian Mutu Pendidikan, Vol. 2, No. 2 (2019): $245-264$.

Musahadah, Sulis Triyono dan Zahrina Sanni. "Fenomena Hijrah di Indonesia: Konten Persuasif dalam Instagram," Retorika: Jurnal Bahasa, Sastra, dan Pengajarannya, Vol. No. 9, No. 2 (2019): 90-163. 
Musthofa. "Kedatangan Islam dan Pertumbuhan Pondok Pesantren di Indonesia Perspektif Filsafat Sejarah," An-Nuha, Vol. 2, No. 1, (2015): 1-15.

Nisa, Eva F. "Social Media and the Birth of an Islamic Social Movement: ODOJ (One Day One Juz) In Contemporary Indonesia," Indonesia and The Malay World, Vol. 46, No. 134 (2018):24-43.

Octavianti, Meria dan Nur Ratih Affandi, Komunikasi Dakwah Pemuda Hijrah." Jurnal Manajemen Komunikasi, Vol. 3, No. 2 (2019): 173-184.

Pawestri, Siti Kholifah dan Wisnu Pudji. "Fashion: Akumulasi Modal dan Habituasi pada Praktik Dakwah Komunitas Hijrah," Religious: Jurnal Studi AgamaAgama dan Lintas Budaya, Vol. 4, No. 3 (2020): 145-160.

Qomar, Mujamil. "Ragam Identitas Islam di Indonesia dari Perspektif Kawasan," Epistemé: Jurnal Pengembangan Ilmu Keislaman, Vol. 10, No. 2 (2015): 317 352.

Rahmawati. "Peran Akhlak Tasawuf dalam Masyarakat Modern," Al-Munzir, Vol. 8, No. 2 (2015): 241-245.

Rokhmad, Abu. "Radikalisme Islam dan Upaya Deradikalisasi Paham Radikal," Walisongo: Jurnal Penelitian Sosial Keagamaan, Vol. 20, No. 1 (2012): 79114.

Sabirin, Rahimi. Islam dan Radikalisme, Yogyakarta: Ar-Rasyid, 2004.

Salim, Agus. "Peran dan Fungsi Dai dalam Perspektif Psikologi Dakwah," AlHikmah: Media Dakwah, Komunikasi, Sosial dan Budaya, Vol. 8, No. 1 (2018): 92-107.

Salim. "Peran dan Fungsi Dai dalam Perspektif Psikologi Dakwah", Al-Hikmah, Vol. 9, No. 14 (2017): 92-107.

Sari, Trie Yunita \& Fatimah Husein, "Hijrah and Islamic Movement in Social Media: a Social Movement Study of Anti-Dating Movement \#Indonesiatanpapacaran," Dinika: Academic Journal of Islamic Studies, Vol. 5, No 1 (2020): 1-26.

Setiawan, Erik. "Makna Hijrah pada Mahasiswa Fikom Unisba di Komunitas (Followers) Account Line@Dakwahislam," Mediator: Jurnal Komunikasi, Vol. 11, No 1 (2017): 127-151

Suarni. "Sejarah Hijrah dalam Perspektif Al-Qur'an," Jurnal Ilmiah Al-Mu'ashirah, Vol. 13, No. 2 (2017): 144-156.

Suharto, Babun. "Islam Profetik: Misi Profetik Pesantren sebagai Sumber Daya Ummat," Tadris: Jurnal Pendidikan Islam, Vol. 14, No. 1 (2019): 96-114.

Sunarto, Raden Intan. "Peran Pondok Pesantren dalam Pengembangan Kultur Islam Nusantara," Al-Tadzkiyyah: Jurnal Pendidikan Islam, Vol. 6, No. 2 (2015): 185-197.

Syahrin, Bunga Mustika dan Alif Alfi, "Makna Hijrah bagi Kalangan Remaja Non Santri: Dampak Penggunaan Media Sosial," Jurnal Studi Agama dan Masyarakat, Vol. 16, No. 1 (2020): 61-72. 
Tajuddin, Yuliyatun. "Walisongo dalam Strategi Komunikasi Dakwah," Addin: Media Dialektika Ilmu Islam, Vol. 8, No. 2 (2014): 367-390.

Taufik, Amalia dan Taufik, M., "Hijrah as a Trend of Islamic Pop Culture among Students in Lombok, West Nusa Tenggara," Teosofia, Vol. 8, No. 2 (2020): 97-116.

Yurisa, Penny Respati et.al. "The Meaning of Hijrah among Niqobers in Social Media," Analisa: Journal of Social Science and Religion, Vol. 5, No. 2 (2020): 201-220

Yusri, Fathayatul Husna. "Kajian Musawarah: Contemporary Da'wah, Pious Identity and Virtual Ummah," Jurnal Ilmiah Islam Futura, Vol. 21, No. 1 (2021): 117134.

Yusri. "Kajian Musawarah: Contemporary Da'wah, Pious Identity and Virtual Ummah", Jurnal Ilmiah Islam Futura, Vol. 21, No. 2 (2021): 117-134.

Yuwanamu, Irham. "Bentuk Islam Faktual: Karakter dan Tipologi Islam Indonesia," El-Harakah, Vol. 8, No. 2 (2016): 199-221.

Zuhdi, Muhammad. “Challenging Moderate Muslims: Indonesia's Muslim Schools in the Midst of Religious Conservatism," Religions, Vol. 9, No. 10 (2018): 1-15.

\section{Informant:}

R1 (female), an Islamic University student in Bandung.

R2 (male), an Islamic University student in Bandung.

R3 (female), an Islamic University student in Bandung.

R4 (female), a State University student in Yogyakarta.

R5 (male), an Islamic University student in Bandung.

R6 (male), a State University student in Yogyakarta. 